\title{
Förderungspreis 2022 der Schweizerischen Gesellschaft für Phlebologie (SGP)
}

Die Schweizerische Gesellschaft für Phlebologie (SGP-SSP) vergibt jährlich einen Förderungspreis im Betrag von 10000,- SFr. Dadurch soll die wissenschaftliche Forschung, die technologische Entwicklung und die klinische Bildung auf dem Gebiet der Phlebologie im weitesten Sinne unterstützt werden. Berücksichtigt werden Arbeiten und Projekte, welche sich in einem fortgeschrittenen Stadium befinden und innerhalb eines Jahres abgeschlossen werden können.
Bewerber richten ein ausführliches Gesuch an den Präsidenten der Schweizerischen Gesellschaft für Phlebologie, Prof. Dr. med. Jürg Hafner, Universitätsspital Zürich, CH8091 Zürich (E-Mail: juerg.hafner@usz.ch). Das Protokoll soll per Mail gesendet werden (PDF-Format) und detaillierte Angaben über die Verwendung der Preissumme enthalten. Die Begutachtung des Gesuches erfolgt durch den Vorstand der Schweizerischen Gesellschaft für Phlebologie. In der Publikation soll z. B. unter „Verdankung oder Unterstützung oder Acknowledgement" der Vermerk „Ausgezeichnet mit dem Förderungspreis der Schweizerischen Gesellschaft für Phlebologie“ stehen. Die Resultate sind im Rahmen einer Veranstaltung der SGP vorzustellen.

\section{Eingabetermin: 31. August 2022}

Benachrichtigung des Preisträgers: September 2022 


\section{Prix scientifique 2022 de la Société Suisse de Phlébologie (SSP)}

La Société Suisse de Phlébologie (SSP-SGP) attribue chaque année un prix scientifique d'un montant de SFr. 10'000.-, dont le but est d'encourager la recherche scientifique, le développement technologique et la formation clinique en phlébologie. Seront pris en considération des travaux et des projets scientifiques déjà suffisamment avancés pour pouvoir être terminés dans le délai d'une année.

Les candidats au prix adresseront une demande détaillée par email (PDF)au président de la Société Suisse de Phlébologie, Prof. Dr. med. Jürg Hafner, Universitätsspital Zürich CH-8091 Zürich (E-Mail: juerg.haf ner@usz.ch). Ce rapport définira de façon détaillée, la manière dont le candidat envisage d'utiliser le montant du prix. La demande sera examinée par le comité de la Société Suisse de Phlébologie. Le travail, lors de sa publication, mentionnera sous $\mathrm{p}$. ex. "remerciement ou soutien ou acknowledgement " qu'il a été „honoré du Prix de la Société Suisse de Phlébologie“. Les résultats de cette recherche devront être présentés au cours d'une réunion officielle de la SSP.

\section{Délai d'inscription: 31 aout 2022}

Avis au lauréat du Prix: septembre 2022

\section{Scientific award 2022 of the Swiss Society of Phlebology (SSP)}

The Swiss Society of Phlebology (SSP-SGP) provides an annual ccientific award of CHF 10'000.-. It's aim is to promote scientific research, technical development and clinical skill in phlebology. Only advanced research and projects capable of being finished within a year delay may be considered.

Candidates for this award should submit a detailed request per email (PDF file) to the president of the Swiss Society of Phlebology, Prof. Dr. med. Jürg Hafner, Universitätsspital Zürich CH-8091 Zürich (E-Mail: juerg. hafner@usz.ch). This request should precisely define the utilization of the amount of the award and will be assessed by the board of the Swiss Society of Phlebology. Publication of any results would have to mention, e. g. under "acknowledgement", that the project has been supported by the „Award of the Swiss Society of Phlebology" The finalised paper should be presented at one of the next official meetings of the SSP.

Deadline: August 31, 2022

Announcement of the winner: September 2022

\section{IMPRESSUM}

Verantwortlich für Mitteilungen der SGP:

Prof. Dr. med. Jürg Hafner, Zürich 